\title{
Lactation performance and digestibility of forages and diets in dairy cows fed a hemicellulose extract
}

\author{
K. J. Herrick, ${ }^{\star}$ A. R. Hippen, ${ }^{\star}$ K. F. Kalscheur, ${ }^{* 1}$ J. L. Anderson, ${ }^{\star}$ S. D. Ranathunga, ${ }^{\star}$ \\ R. S. Patton, $†$ and M. Abdullahł \\ *Department of Dairy Science, South Dakota State University, Brookings 57007 \\ †Galisteo, NM 87540 \\ $\ddagger$ Department of Livestock Production, University of Veterinary and Animal Sciences, Lahore 54000, Pakistan
}

\section{ABSTRACT}

Inclusion of hemicellulose extract (HE) in cattle diets have shown potential for improving fiber digestibility and production efficiency. The objective of this research was to evaluate production and digestibility effects of a HE on midlactation cows. Twelve multiparous Holstein cows (142 $\pm 44 \mathrm{~d}$ in milk, $685 \pm 19 \mathrm{~kg}$ of body weight) including 4 with ruminal fistula were used in a $2 \times 2$ Latin square design with 21-d periods. Cows were fed a control $(\mathrm{CON})$ diet containing $55 \%$ forage [dry matter (DM) basis, $2 / 3$ corn silage and $1 / 3$ alfalfa hay] or a similar diet where $1.0 \%$ of the diet DM was replaced with HE (TRT). Dry matter intake averaged 27.1 and $26.9 \mathrm{~kg} / \mathrm{d}$, for CON and TRT respectively, and was not affected by addition of extract. The percentage of milk protein (3.40 vs. 3.29\%) was greater, whereas the percentage of milk fat (3.91 vs. $3.80 \%$ ) tended to be greater, for cows fed the CON compared with the TRT diet. Because of numerically greater milk production (38.8 vs. $39.2 \mathrm{~kg} / \mathrm{d}$ ) for cows fed the TRT diet, no differences were observed in component yields other than lactose (1.86 vs. $1.94 \mathrm{~kg} / \mathrm{d})$, which tended to be greater for cows fed the TRT ration. Treatment improved neutral detergent fiber (NDF) digestibility (38.6 vs. $48.1 \%$ ) for the TRT diet compared with the CON diet but did not affect apparent total-tract DM (67.8 vs. $68.5 \%)$, crude protein (67.2 vs. $67.9 \%$ ), acid detergent fiber (ADF; 37.1 vs. $43.3 \%$ ), or starch (92.8 vs. $92.2 \%$ ) digestibility. For in situ determinations, Dacron bags containing corn silage, alfalfa hay, and either the CON or TRT ration were incubated in triplicate in the rumens of the cannulated cows at $0,3,6,9,12,24$, and $48 \mathrm{~h}$ on d 18 of each period. Each total mixed ration was incubated only in cows assigned to the corresponding diet. For corn silage, the rate of disappearance of NDF (1.70 vs. $4.27 \%$ ) and $\mathrm{ADF}$ (1.79 vs. $4.66 \%$ ) increased for cows fed the TRT diet. For alfalfa hay, the disappearance

Received November 21, 2011.

Accepted February 5, 2012.

${ }^{1}$ Corresponding author: kenneth.kalscheur@sdstate.edu of fraction A of DM, NDF, and ADF decreased and fraction B of DM and NDF increased with treatment. The rate of disappearance for DM (8.03 vs. $11.04 \%$ ), NDF (6.30 vs. $10.28 \%$ ), and ADF (5.52 vs. 9.19\%) increased for the alfalfa hay in rumens of treated cows. For the total mixed ration, the disappearance of the $\mathrm{A}$ fraction of NDF and ADF increased for cows fed the TRT diet. Supplementing diets of lactating dairy cows with an HE has beneficial effects on fiber degradation characteristics and provides opportunities for improving animal performance.

Key words: dairy cow, digestibility, forage, hemicellulose extract

\section{INTRODUCTION}

Sugars have effectively been used in dairy cow diets to offer alternatives to more expensive feed ingredients or to promote performance (Hall et al., 2010). It is believed that some of the improvement observed from sugar supplementation can be attributed to optimizing microbial growth by synchronizing protein and carbohydrate degradation (Kim et al., 1999). Researchers have demonstrated an effect of sugars on fermentation patterns and performance when readily fermentable carbohydrates are fed with different protein sources that vary in ruminal degradation characteristics (Broderick and Radloff, 2004; Golombeski et al., 2006; Penner and Oba, 2009). Furthermore, Hoffman and Bauman (2003) reported increased DMI, milk production, and component yield when lactating cows being fed red clover silage were supplemented with $4.2 \%$ dextrose. Much of this early work focused on including sugars in the diets at a relatively large percentage $(>4.0 \%$ of diet DM). Additional research needs to be conducted to further understand the effects of supplementing sugars at lower inclusion amounts similar to other feed additives.

Previous research demonstrated that individual sugars have different effects on ruminal molar proportions of VFA, supply of microbial nitrogen to the small intestine, and ruminal ammonia (Chamberlain et al., 1993). Additionally, differences have occurred in rumen 
protozoa population when lactating dairy cows were fed either starch or a source of readily fermentable sugars (Abou Akkad et al., 1969). This response has led research to commercially available sources of sugars, such as hemicellulose extracts ( $\mathbf{H E}$ ) that could be used by the dairy industry to enhance performance. Hemicellulose extracts were found to contain a dilute amount of xylooligosaccharides and acetic acid as the major components, and many minor components including other organic acids, lignin-derived phenolics, and sugar degradation products (Walton, 2005). Early heifer research with yearling Holsteins demonstrated that HE treated with ammonia allowed similar performance as soybean meal (Magruder et al., 1953). Some of the first HE research as a feed ingredient in dairy cow diets dates back over $40 \mathrm{yr}$ to when researchers at Kansas State University (Manhattan) compared substituting hemicellulose extract for liquid molasses at an inclusion rate of $10 \%$ of the grain ration in lactating dairy rations (Bartley et al., 1968). The researchers did not detect any differences in milk production or milk components and concluded that hemicellulose extract had a feeding value similar to cane molasses when included at a rate of $10 \%$ of the grain component. These results were substantiated when Crawford et al. (1978) found no difference in performance of beef steers when 2 types of HE were compared against cane molasses. Additionally, in vitro work by Hartnell and Satter (1978) reported that an $\mathrm{HE}$ derived from masonite board production had the ability to protect soybean meal from degradation by rumen microbes.

Much of this research was conducted several decades ago and was done using animals with vastly different production characteristics than modern dairy cattle. Furthermore, characteristics of HE vary depending upon source of woody biomass and method of hemicellulose extraction (Tunc and van Heiningen, 2008). The objective of this work was to evaluate the digestive and production characteristics in midlactation Holstein dairy cows supplemented with Temulose (Temple Inland Inc., Austin, TX), which is a specific HE coproduct from the forestry industry.

\section{MATERIALS AND METHODS}

\section{Production Experiment}

Animal care and use was approved by the South Dakota State University (Brookings) Institutional Animal Care and Use Committee. Twelve Holstein cows (8 multiparous and 4 primiparous with rumen cannulas) averaging $142( \pm 46)$ DIM and $41.9( \pm 5.56) \mathrm{kg} / \mathrm{d}$ milk yield were used in a $2 \times 2$ replicated Latin Square design with 21-d periods. Cows were blocked according to production and parity and randomly assigned within block to 1 of 2 treatment diets. The control diet (CON) contained $55 \%$ forage DM (2/3 corn silage, $1 / 3$ alfalfa hay) and was formulated to contain $30.0 \%$ NDF, $18.6 \%$ $\mathrm{ADF}, 17.8 \% \mathrm{CP}$, and $39.5 \% \mathrm{NFC}$ on a DM basis. The treatment diet (TRT) was similar to CON except that HE (Temulose; Temple Inland Inc.) was added at 1.0\% of diet DM (Table 1). Temulose HE is a natural product manufactured by steam extraction of select species of wood. It consists of approximately $70 \%$ sugars, $4 \%$ ash, and less than $1 \%$ protein or fat (DM basis). This HE contains a total dietary nutrient content (78\%) and net energy values $\left(\mathrm{NE}_{\mathrm{M}} 1.85 \mathrm{Mcal} / \mathrm{kg}\right)$ similar to cane molasses, but possesses a distinct sugar composition contrasted with the sucrose in molasses. Mannose is the predominant sugar $(36.4 \%)$ in $\mathrm{HE}$, followed by xylose $(13.2 \%)$, glucose $(11.5 \%)$, galactose $(7.32 \%)$, arabinose $(0.13 \%)$, fucose $(0.08 \%)$, and rhamnose $(0.04 \%)$. Sixty to $70 \%$ of the sugars are present in oligomeric form (Faber et al., 2011).

All cows were housed in a freestall barn at the South Dakota State University Dairy Teaching and Research Center (Brookings). Forages were premixed in a vertical mixer and blended with concentrates in a Calan Data Ranger (America Calan Inc., Northwood, NH). Diets were individually fed as a TMR for ad libitum intake once daily $(0800 \mathrm{~h})$ using Calan Broadbent individual animal feeders (American Calan Inc.). Orts were weighed once daily and the diet offered was adjusted to ensure $10 \%$ feed refusal. Cows were trained to the Calan gates for a week before initiating the experiment and individual milk production and DMI was recorded daily for the entire study. Weeks 1 and 2 of each period were allowed for adjustment to the diet, whereas data collection for each period occurred during wk 3 .

Samples of the TRT and CON diets and individual orts from each cow were collected at the end of each period for 3 consecutive days, composited for period and animal, and immediately frozen at $-20^{\circ} \mathrm{C}$ until analysis. All feed samples and orts were dried in duplicate at $55^{\circ} \mathrm{C}$ for $48 \mathrm{~h}$ in a Despatch oven (style V-23; Despatch Industries Inc., Minneapolis, MN), and then ground to a 2-mm particle size (Wiley mill, model 3; Arthur H. Thomas Co., Philadelphia, PA). Samples were then further ground to a 1-mm particle size using an ultracentrifuge mill (Brinkman Instruments Co., Westbury, NY) and analyzed for DM, NDF, ADF, CP, starch, and titanium dioxide as described in the Laboratory Analyses section.

Cows were milked 3 times daily at 0600, 1400, and 2100 h. Milk samples were collected from each cow for each milking for 3 consecutive days (d 17-19) of each period. Milk samples from each milking and cow were sent to Heart of America DHIA Laboratory (Manhat- 
Table 1. Ingredient and nutrient composition of control (CON) and treatment (TRT) diets

\begin{tabular}{|c|c|c|}
\hline \multirow[b]{2}{*}{ Composition } & \multicolumn{2}{|c|}{ Diet } \\
\hline & $\mathrm{CON}$ & TRT \\
\hline \multicolumn{3}{|l|}{ Ingredient ( $\%$ of DM) } \\
\hline Corn silage & 36.7 & 36.2 \\
\hline Alfalfa hay & 18.3 & 18.1 \\
\hline Soybean meal, $44 \%$ & 11.8 & 11.8 \\
\hline Corn grain, high moisture & 9.85 & 9.71 \\
\hline Corn grain, dry ground & 6.57 & 6.57 \\
\hline Cottonseed, whole & 7.55 & 7.45 \\
\hline Dried distillers grains with solubles & 5.26 & 5.26 \\
\hline Limestone & 1.14 & 1.14 \\
\hline Rumen inert fat ${ }^{1}$ & 0.81 & 0.81 \\
\hline Sodium bicarbonate & 0.49 & 0.49 \\
\hline Salt, white & 0.41 & 0.41 \\
\hline Potassium carbonate $^{2}$ & 0.36 & 0.36 \\
\hline Ca 17\%:P 21\% & 0.24 & 0.24 \\
\hline Magnesium oxide & 0.19 & 0.19 \\
\hline Urea & 0.18 & 0.18 \\
\hline Vitamin/trace minerals pack ${ }^{3}$ & 0.13 & 0.13 \\
\hline Trace minerals ${ }^{4}$ & 0.02 & 0.02 \\
\hline Hemicellulose extract ${ }^{5}$ & 0.00 & 0.98 \\
\hline $\mathrm{DM}(\%$, as fed $)$ & 56.3 & 56.6 \\
\hline \multicolumn{3}{|l|}{ Nutrient composition (\% of DM) } \\
\hline $\mathrm{CP}$ & 17.5 & 17.8 \\
\hline RUP $^{6}$ & 5.81 & 5.91 \\
\hline NDF & 30.6 & 30.9 \\
\hline $\mathrm{ADF}$ & 18.1 & 17.8 \\
\hline $\mathrm{NFC}^{6}$ & 39.5 & 39.4 \\
\hline Starch & 21.4 & 21.1 \\
\hline $\mathrm{NE}_{\mathrm{L}}^{6}($ mcal $/ \mathrm{kg})$ & 1.65 & 1.67 \\
\hline
\end{tabular}

${ }^{1}$ Energy Booster 100 (Milk Specialties Co., Dundee, IL).

${ }^{2}$ DCAD Plus (Church and Dwight Co., Princeton, NJ).

${ }^{3}$ BioSel Dairy Forti-P, (Vita Plus Corp., Madison, WI).

${ }^{4}$ Zinpro 4-Plex (Zinpro Corp., Eden Prairie, MN).

${ }^{5}$ Temulose (Temple Inland Inc., Austin, TX).

${ }^{6}$ Calculated according to NRC (2001) using analyzed feed values.

$\tan , \mathrm{KS}$ ) for analysis. Mid-infrared spectroscopy (Bentley 2000 Infrared Milk Analyzer; Bentley Instruments, Chaska, MN; AOAC, 2002) was used to analyze milk fat, protein, and lactose, whereas MUN concentration was determined using chemical methodology based on a modified Berthelot reaction (ChemSpec 150 Analyzer; Bentley Instruments). Somatic cell counts were determined using a flow cytometer laser (Somacount 500; Bentley Instruments; AOAC, 2002). Energy-corrected milk was calculated using the following equation: $\{[0.327$ $\times$ milk yield $(\mathrm{kg})]+[12.95 \times$ fat yield $(\mathrm{kg})]+[7.2 \times$ protein yield (kg)] (Orth, 1992).

Rumen fluid was collected from the 4 cannulated cows on d 20 of period 1 and d 23 of period 2 at 0,3 , 6,9 , and $12 \mathrm{~h}$ relative to feeding. Feeding of both CON and TRT was extended to $\mathrm{d} 23$ of period 2 to facilitate collection of rumen fluid. Samples of rumen fluid were taken from the cranial, central, and caudal portions of the rumen via a filtered probe and tube attached to a 50-mL syringe. Ten milliliters of rumen fluid was added to a vial containing $2 \mathrm{~mL}$ of $25 \%$ (wt/vol) metaphosphoric acid and immediately frozen at $-20^{\circ} \mathrm{C}$ until VFA analysis. An additional $10 \mathrm{~mL}$ of rumen fluid to be used for ammonia analysis was added to a separate vial containing $200 \mu \mathrm{L}$ of $50 \%$ (vol/vol) $\mathrm{H}_{2} \mathrm{SO}_{4}$ and frozen at $-20^{\circ} \mathrm{C}$.

Body weights and BCS were recorded over 3 consecutive days at the beginning of the experiment, at the end of the first period, and then again at the end of the experiment. Body condition scores were recorded independently by 3 individuals on a scale of 1 to 5, where 1 represented emaciated and 5 represented obese (Wildman et al., 1982).

\section{Digestibility Experiment}

The 8 cows without rumen cannulas were used in a digestibility study to determine the effects of TRT on total-tract digestibility estimates of DM, NDF, ADF, $\mathrm{CP}$, and starch. From d 13 to 20 in each period, 20 $\mathrm{g}$ of titanium dioxide was added to each cow's TMR immediately after feeding and hand mixed with the upper portion of the TMR to guarantee consumption. A total of 12 fecal samples were collected on d 18 to 20. Sampling times were staggered such that the entire 24-h day was represented to avoid diurnal variation. A similar volume of feces on a wet basis was collected from each cow for each time point and composited for each cow and stored at $-20^{\circ} \mathrm{C}$ until analysis. Fecal composites were thawed and samples were placed in duplicate containers for freeze drying before analysis. After freeze drying, the fecal samples were ground to pass a $2-\mathrm{mm}$ screen (Wiley mill; Arthur H. Thomas Co.) and then further ground to a 1-mm particle size using an ultracentrifuge mill. Ground samples were analyzed for DM, NDF, ADF, CP, starch, and titanium dioxide.

\section{In Situ Experiment}

Four primiparous cannulated cows were used in an in situ study to determine rumen disappearance characteristics of alfalfa hay (AH), corn silage (CS), CON, and TRT in cows fed either the CON or TRT diets. Samples of AH, CS, CON, and TRT from each period were dried at $55^{\circ} \mathrm{C}$ for $48 \mathrm{~h}$ in a Despatch oven and then ground to a 2-mm particle size (Wiley mill). Triplicate Dacron bags containing approximately $5 \mathrm{~g}$ of $\mathrm{AH}, \mathrm{CS}$, and either CON or TRT were weighed into nylon bags $(10 \times 20 \mathrm{~cm}, 53 \pm 10-\mu \mathrm{m}$ pore size; R1020; Ankom Technology Corp., Macedon, NY), heat sealed, and incubated in the rumens for $0,3,6,12,24$, and 48 h. Sample bags with CON were placed only in those cows receiving the CON diet and, likewise, samples of TRT were only incubated in those cows receiving the 
TRT diet. Before incubation, all bags were soaked in water $\left(39^{\circ} \mathrm{C}\right)$ for $15 \mathrm{~min}$ and then placed in a larger, weighted mesh bag $(36 \times 42 \mathrm{~cm})$ that was suspended below the particulate mat layer in the ventral sac of the rumen. Bags were inserted in reverse order and all were removed at the same time. After removal, the bags were immediately immersed in cold water to arrest bacterial growth and then hand washed to remove any external particulate material. Bags were allowed to air dry for a period of $24 \mathrm{~h}$ and then placed in a $55^{\circ} \mathrm{C}$ Despatch oven for $48 \mathrm{~h}$. Bags were individually weighed and composited for each time point for each cow. Samples of $\mathrm{CS}, \mathrm{AH}, \mathrm{CON}$, and TRT were analyzed for DM, NDF, $\mathrm{ADF}, \mathrm{CP}$, and starch.

\section{Laboratory Analyses}

Dry matter content was determined at $105^{\circ} \mathrm{C}$ for 3 h (Shreve et al., 2006). Concentrations of NDF (Van Soest et al., 1991) and ADF (Robertson and Van Soest, 1981) were determined sequentially using an Ankom fiber analyzer (Ankom Technology Corp.). Sodium sulfite and $\alpha$-amylase were added during NDF extraction. Nitrogen concentration was determined according to AOAC (2002; method 968.06) using an automated $\mathrm{N}$ combustion analyzer (Rapid N cube; Elementar Analysensysteme GmbH, Hanau, Germany). Crude protein concentration was reported as 6.25 multiplied by the nitrogen concentration. Starch concentration was determined using an amylase assay kit (Megazyme International Ireland Ltd., Wicklow, Ireland; AOAC, 2002; method 996-11).

Titanium dioxide was chosen as a marker to estimate total-tract digestibility (Glindemann et al., 2009). The concentration of titanium dioxide was measured according to the procedure of Myers, et al. (2004) with a few modifications (P. A. Ludden, University of Wyoming, Laramie, personal communication, 2010). Briefly, 250 $\mathrm{mL}$ macro-Kjeldahl digestion tubes were washed in a $10 \%$ (vol/vol) $\mathrm{HCl}$ bath and weighed. Standards were prepared by accurately weighing $0,2,4,6,8$, and 10 $\mathrm{mg}$ of titanium dioxide into the macro-Kjeldahl digestion tubes. Standards and samples of feed and feces were treated in the same manner except that duplicate 0.5-g samples were used for the feed and fecal samples. Samples of feces and feed devoid of titanium dioxide were used as a baseline. Approximately $3.5 \mathrm{~g}$ of $\mathrm{K}_{2} \mathrm{SO}_{4}, 0.4 \mathrm{~g}$ of $\mathrm{CuSO}_{4}$, and $13 \mathrm{~mL}$ of concentrated $\mathrm{H}_{2} \mathrm{SO}_{4}$ were added to each tube containing the samples or standards. The tubes were vortexed and placed in a Kjeldahl digestion block preheated to $420^{\circ} \mathrm{C}$. The temperature was allowed to return to $420^{\circ} \mathrm{C}$ and the samples were digested for $2 \mathrm{~h}$. Following digestion, the tubes were removed from the digestion block, allowed to cool, after which $15 \mathrm{~mL}$ of $30 \% \mathrm{H}_{2} \mathrm{O}_{2}$ was added to each tube. The tubes were once again allowed to cool and distilled water was added to each digestion tube to bring the total liquid weight to $100 \mathrm{~g}$. The samples were vortexed and filtered through Whatman 54 filter paper into a 250-mL Erlenmeyer flask. Just before reading, approximately 5 drops of $30 \% \mathrm{H}_{2} \mathrm{O}_{2}$ were added to each flask and gently swirled. Samples were read using a sipper attachment on a Cary 50 Bio UV Visible Spectrophotometer (Varian Inc., Palo Alto, CA) with a wavelength of $410 \mathrm{~nm}$. The 0 standard was used to zero the instrument. The concentration of titanium dioxide was calculated according to the equation generated from the standard curve and the average absorbance of 3 readings from each sample. The baseline titanium dioxide concentration of feed and feces was subtracted from the corresponding samples to obtain a final titanium dioxide concentration. To validate the procedure, 4 and $8 \mathrm{mg}$ of titanium dioxide was spiked to $0.5 \mathrm{~g}$ of both fecal and TMR sample. The recovery of titanium dioxide was $95.0 \%$ for the TMR sample and $90.4 \%$ for the fecal sample.

Rumen fluid samples containing $\mathrm{H}_{2} \mathrm{SO}_{4}$ were thawed, centrifuged for $20 \mathrm{~min}$ at $30,000 \times g$ and analyzed for ammonia N according to Chaney and Marbach (1962). Rumen fluid samples containing metaphosphoric acid were thawed, centrifuged at $30,000 \times g$ for $20 \mathrm{~min}$ and analyzed for acetate, propionate, butyrate, isobutyrate, isovalerate, and valerate. Concentrations of VFA were measured using an automated gas-liquid chromatograph (model 6890; Hewlett-Packard Co., Palo Alto, CA) using a flame-ionization detector. Volatile fatty acids were separated on a capillary column $(15 \mathrm{~m} \times 0.25 \mathrm{~mm}$ i.d.; Nukol, 17926-01C; Supelco Inc., Bellefonte, PA) using 2-ethylbutyrate as an internal standard. The split ratio of 100:1 in the injector port was at a temperature of $250^{\circ} \mathrm{C}$ with flow rate of $1.3 \mathrm{~mL} / \mathrm{min}$ of helium. The column and detector temperature were maintained at $140^{\circ} \mathrm{C}$ and $250^{\circ} \mathrm{C}$, respectively.

\section{Mathematical and Statistical Analyses}

All data were analyzed by the MIXED procedure in SAS (version 9.2; SAS Institute, 2008). Milk production and feed intake were averaged over the final week of each period. Means for the remaining variables were calculated from the data gathered during the collection time for each period. The model for feed intake, milk yield, milk composition, and apparent digestibility variables was $\mathrm{Y}=$ period + treatment + block + $($ treatment $\times$ period $)+($ treatment $\times$ block $)$, where $Y$ was the variable of interest and the random effect was cow. The same model was used for BW change and BCS change. The model for VFA, rumen $\mathrm{pH}$, and 
rumen ammonia was $\mathrm{Y}=$ period + time + treatment $+($ time $\times$ treatment $)+($ period $\times$ treatment $\times$ time $)$, where $\mathrm{Y}$ was the variable of interest and the random effect was cow. Time was considered a repeated measure. The variance-covariance error structure was antedependence covariance, which was selected based on the lowest Akaike information criterion fit statistic.

Nonsignificant interactions were sequentially dropped from the model. Significant interactions are identified in the results and tables. Least squares means are reported for each variable and statistical significance of main effects was declared at $P \leq 0.05$ and tendencies were discussed at $0.05 \leq P \leq 0.10$.

In situ degradation curves for DM, NDF, ADF, and starch were fitted to a nonlinear model (Ørskov and McDonald, 1979) without a lag phase as described by the following equation:

$$
\mathrm{Y}=\mathrm{A}+\mathrm{B}\left(1-\mathrm{e}^{-\mathrm{K}_{\mathrm{d}}(\mathrm{t})}\right)
$$

where $\mathrm{Y}=$ ruminal disappearance $(\%) ; \mathrm{A}=$ fraction that disappeared at $0 \mathrm{~h}$ after the rinsing procedure; $\mathrm{B}=$ potentially degradable fraction; $\mathrm{e}=$ base for the natural logarithm; $\mathrm{K}_{\mathrm{d}}=$ constant rate of degradation of fraction $\mathrm{B}$; and $t=$ time of incubation $(\mathrm{h})$. The undegradable fraction $\mathrm{C}$ was calculated as $100-(\mathrm{A}+\mathrm{B})$. Effective degradability was determined by the equation

$$
\text { effective degradability }=\mathrm{A}+\mathrm{B}\left[\mathrm{K}_{\mathrm{d}} /\left(\mathrm{K}_{\mathrm{d}}+\mathrm{K}_{\mathrm{p}}\right)\right] \text {, }
$$

where $\mathrm{A}, \mathrm{B}$, and $\mathrm{K}_{\mathrm{d}}$ are the degradation constants described previously (Ørskov and McDonald, 1979). The rate of disappearance $\left(\mathrm{K}_{\mathrm{p}}\right)$ from the rumen $(\% / \mathrm{h})$ was calculated using the NRC (2001) equations for wet forages, dry forages, and concentrates. The passage rate for CS was calculated using the equation

$$
\mathrm{K}_{\mathrm{p}}=3.054+0.614 \mathrm{X}_{1},
$$

where $\mathrm{X}_{1}=\mathrm{DMI}$ as a percentage of BW.

The passage rate for $\mathrm{AH}$ was calculated using the equation

$$
\mathrm{K}_{\mathrm{p}}=3.362+0.479 \mathrm{X}_{1}-0.007 \mathrm{X}_{2}-0.017 \mathrm{X}_{3},
$$

where $\mathrm{X}_{1}=\mathrm{DMI}$ as a percentage of $\mathrm{BW}, \mathrm{X}_{2}=$ concentrate as a percentage of diet DM, and $\mathrm{X}_{3}=\mathrm{NDF}$ of $\mathrm{AH}$ as a percentage of DM.

The passage rate for CON and TRT was calculated using the equation

$$
\mathrm{K}_{\mathrm{p}}=2.904+1.375 \mathrm{X}_{1}-0.020 \mathrm{X}_{2},
$$

where $\mathrm{X}_{1}=\mathrm{DMI}$ as a percentage of $\mathrm{BW}$ and $\mathrm{X}_{2}=$ concentrate as a percentage of diet DM.

Energy values were calculated as follows using equations from NRC (2001):

$$
\begin{gathered}
\text { milk } \mathrm{NE}_{\mathrm{L}}(\mathrm{Mcal} / \mathrm{kg})=0.0929 \times(\text { fat } \%)+0.0547 \\
\times(\text { protein } \%)+0.0395 \times(\text { lactose } \%) ; \\
\operatorname{milk~NE}_{\mathrm{L}}(\mathrm{Mcal} / \mathrm{d})=\text { milk yield }(\mathrm{kg}) \\
\times[0.0929 \times(\text { fat } \%)+0.0547 \times(\text { protein } \%) \\
+0.0395 \times(\text { lactose } \%)] \\
\mathrm{NE}_{\mathrm{M}}=0.080 \times \mathrm{BW}^{0.75} .
\end{gathered}
$$

In situ degradation constants $\left(\mathrm{A}, \mathrm{B}, \mathrm{C}\right.$, and $\mathrm{K}_{\mathrm{d}}$ ) and effective degradability were analyzed using the MIXED procedure of SAS (version 9.2; SAS Institute, 2008) for each feed ingredient, with cow as a random variable. The model for all variables was $\mathrm{Y}=$ treatment + period + treatment $\times$ period, where $Y$ was the variable of interest. Mean comparisons were performed using the Tukey test. Least squares means are reported for each variable and statistical significance was declared at $P \leq$ 0.05 and tendencies were discussed at $0.05 \leq P \leq 0.10$.

\section{RESULTS AND DISCUSSION}

\section{Production Experiment}

Production measures did not differ except for a tendency for greater lactose yield for the TRT diet $(P$ $=0.08)$, a tendency for less milk fat percent for the TRT diet $(P=0.06)$, and a significant decrease in milk protein percent for the TRT diet $(P=0.03$; Table 2$)$. This is in agreement with the results of several other researchers who observed no differences in milk yield and milk components when feeding sugar (Golombeski et al., 2006; Broderick et al., 2008; Penner and Oba, 2009) or molasses (Broderick and Radloff, 2004). It should be emphasized that the current research was conducted with a product that contains a variety of sugars and varies considerably in composition compared with the previously mentioned research.

Penner and Oba (2009) supplemented early lactation cows with either 0 or $4.7 \%$ sucrose to provide either 4.5 or $8.7 \%$ total soluble carbohydrates. In that research, no significant differences were observed between the 2 treatments for yield of milk, fat, CP, and lactose. Milk production was numerically greater (34.4 vs. $33.0 \mathrm{~kg}$ ) for the high-sugar diet as compared with the low-sugar treatment. Similarly, Broderick et al. (2008) reported 
Table 2. Milk production and composition in dairy cows fed a control (CON) diet or treatment (TRT) diet containing a hemicellulose extract

\begin{tabular}{lcccc}
\hline Item & CON & TRT & SEM & $P$-value \\
\hline DMI (kg/d) & 27.1 & 26.9 & 0.80 & 0.86 \\
Yield (kg/d) & & & & \\
Milk & 38.8 & 39.2 & 0.64 & 0.55 \\
Fat & 1.52 & 1.48 & 0.04 & 0.39 \\
Protein & 1.31 & 1.29 & 0.03 & 0.58 \\
Lactose & 1.86 & 1.94 & 0.06 & 0.08 \\
SNF & 3.54 & 3.55 & 0.10 & 0.97 \\
MUN & 5.78 & 5.99 & 0.35 & 0.61 \\
FCM, 4.0\% & 38.3 & 38.0 & 0.86 & 0.77 \\
ECM & 41.9 & 41.3 & 0.87 & 0.68 \\
Milk composition (\%) & & & & \\
Fat & 3.91 & 3.80 & 0.03 & 0.06 \\
Protein & 3.40 & 3.29 & 0.08 & 0.03 \\
Lactose & 4.78 & 4.95 & 0.11 & 0.17 \\
SNF & 9.12 & 9.06 & 0.12 & 0.37 \\
SCC (× 1,000 cells/mL) & 308 & 44 & 192 & 0.35 \\
MUN (mg/dL) & 14.9 & 15.3 & 0.74 & 0.66 \\
4.0\% FCM/DMI & 1.49 & 1.47 & 0.12 & 0.89 \\
\hline
\end{tabular}

${ }^{1}$ Trends were observed for interactions between period and treatment for DMI $(P=0.07)$ and protein percentage $(P=0.10)$, and a significant interaction for fat percentage $(P<0.01)$.

${ }^{2}$ Trends were observed for period effect for milk $(P=0.09)$, intake $(P=0.10)$, and fat percentage $(P=0.08)$, and significant effects for MUN $(P=0.05)$, MUN yield $(P=0.05)$, and lactose yield $(P=0.02)$.

no differences in yield of milk, protein, or lactose when early lactation cows were fed diets with increasing amounts of sucrose $(0,2.5,5$, and $7.5 \%)$ substituted for starch. However, the authors did report greater concentration and yield of milk fat as the amount of sucrose in the diet increased. This is in contrast to the results from the current study, which demonstrated that milk fat concentration had a tendency $(P=0.06)$ to decrease with HE treatment. These differences are likely related to differences in the sugar composition and types of forages in the basal diet.

Golombeski et al. (2006) reported an increase in milk fat concentration when $8.6 \%$ of diet DM was replaced with a source of fermentable sugars fed with either urea or a source of slow-release urea. In agreement with results from the current research, those authors observed a tendency for lower yield of milk true protein $(P=$ 0.07 ) for cows fed the fermentable sugar. However, the authors also reported less yield of lactose and concentration of lactose for the fermentable sugar treatments. This is contradictory to the response observed from the current study in which yield of lactose tended to be greater $(P=0.08)$ for the TRT diet.

A portion of these differences could be explained by milk yield. Although milk production difference was not significant for this study, a numerical difference existed. This is probably a result of the tendency for greater milk lactose yield $(P=0.08)$ for the TRT diet, which could have resulted in a dilution effect on the milk fat and protein concentration (Akers, 2002). Several trends and differences also occurred for period effects and interactions between period and treatment. This was most likely explained by the change in environmental conditions between the first and second collection periods. The average temperature during the first collection period was $12.0^{\circ} \mathrm{C}$, with high temperatures approximately $15.5^{\circ} \mathrm{C}$. The second collection period high temperatures were approximately $32.2^{\circ} \mathrm{C}$, with an average temperature of $20.0^{\circ} \mathrm{C}$.

\section{Digestibility Experiment}

Apparent total-tract digestibility values are shown in Figure 1. Dry matter, ADF, CP, and starch apparent total-tract digestibility were not affected by treatment with HE; however, significant improvement in NDF digestibility occurred in the TRT diet. This is in agreement with the results of several other researchers who reported improvement in digestibility characteristics with sugar substitution or addition (Wiedmeier et al., 1992; Broderick and Radloff, 2004; Broderick et al., 2008).

Wiedmeier et al. (1992) fed a sugar product manufactured from a unique extraction process of molasses to cannulated beef cows. These authors reported a $4.46 \%$ improvement in NDF digestibility when a high-grain diet $(33.7 \%$ NDF) was fed. Broderick and Radloff (2004) replaced high-moisture shell corn with increasing amounts of dried or liquid molasses to increase total sugar concentration up to $10 \%$ of diet DM in midlactation Holstein cow diets. These authors observed a linear improvement in $\mathrm{DM}, \mathrm{OM}, \mathrm{NDF}$, and $\mathrm{ADF}$ digestibility 


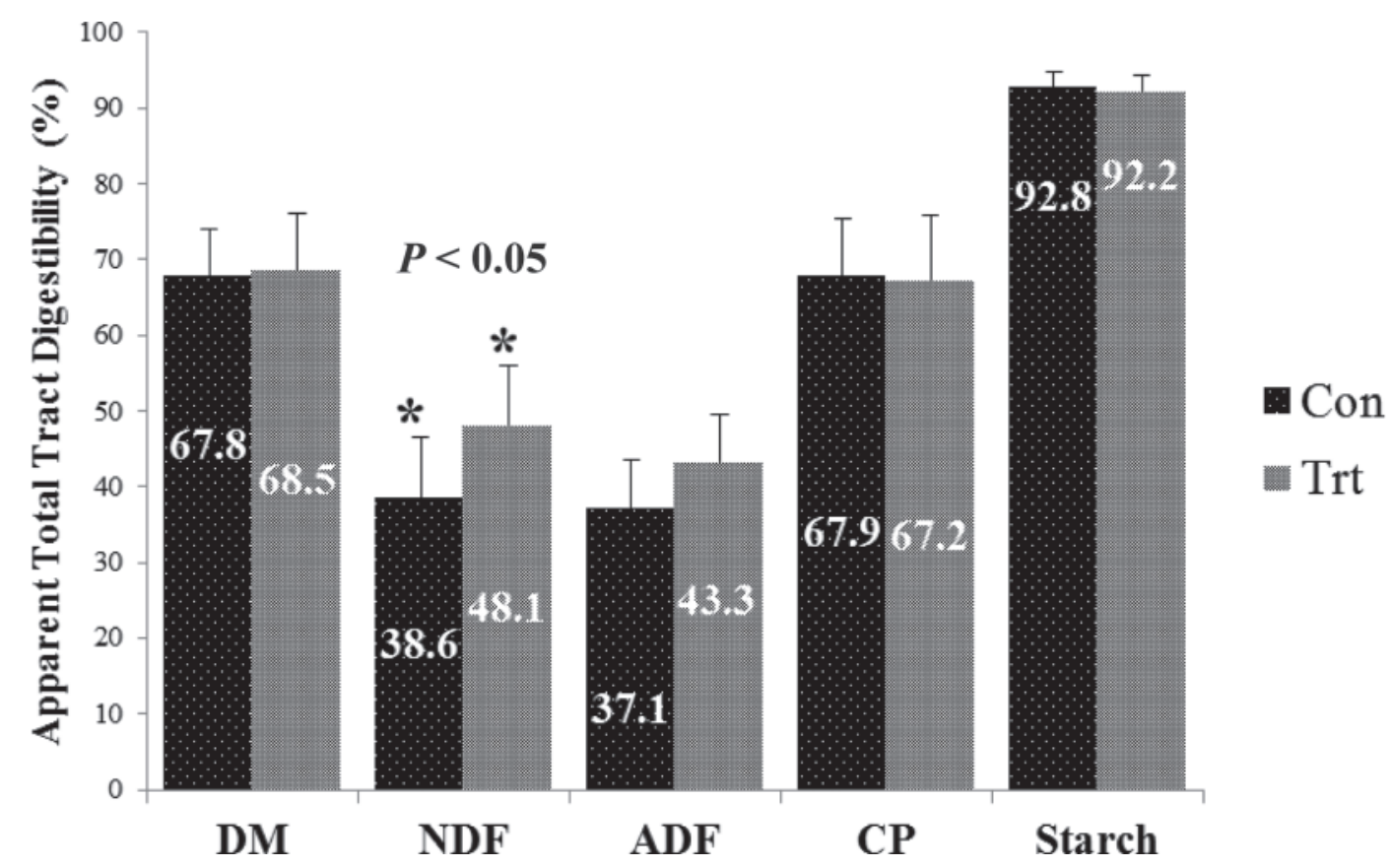

Figure 1. Apparent total-tract digestibilities from cows fed a control (Con; dark bar) or treatment (Trt; light bar) TMR.

with dried molasses substitution up to $7.2 \%$ total sugar in the diet. They also reported a cubic response for these same parameters when liquid molasses instead of dried molasses was used as a substitute for highmoisture shelled corn up to $10 \%$ total sugar in the diet. Digestibility values were greatest when liquid molasses was added at $6 \%$ of the diet to increase the total sugar content to $7.4 \%$ of diet DM. Broderick et al. (2008) added sucrose to early lactation Holstein cows and replaced corn starch at increasing amounts up to $7.5 \%$ sucrose of dietary DM. Digestibility values, based on nutrient flow from and digestion in the rumen, for DM and ADF were not affected by treatment. However, a quadratic response in rumen NDF digestibility values occurred with the diet that contained the $5.0 \%$ sucrose having the greater response. Some authors have reported no differences in digestibility parameters related to sugar supplementation (Penner and Oba, 2009). Penner and Oba (2009) replaced $4.7 \%$ cracked corn with sucrose in postpartum transition cow diets and reported no change in apparent total-tract digestibility for DM, $\mathrm{NDF}$, or starch when cows were fed a low-sugar or highsugar diet in early lactation.

It is of interest to note that in this research, NDF digestibility increased when HE was supplemented at a rate of only $1.0 \%$ of diet DM. Previous research has not demonstrated a strong relationship between sugar supplementation and NDF digestibility when supplemented or substituted at lower inclusion amounts (Broderick and Radloff, 2004; Broderick et al., 2008).
The only responses in lactating cows came when the concentration of sugars was greater than $5.0 \%$ of the diet DM. These experiments were conducted using molasses as a sugar source. This would support previous research that demonstrated a change in rumen parameters when individual sugars were fed to sheep (Chamberlain et al., 1993).

Neutral detergent fiber disappearance for the TMR was $9.5 \%$ greater for the TRT TMR than the CON TMR. Previous research has suggested that for each $1-\mathrm{U}$ increase for in vitro or in situ forage NDF digestibility positively equates to $0.17 \mathrm{~kg}$ of DMI or $0.23 \mathrm{~kg}$ of milk production (Oba and Allen, 1999). Those authors also suggested that NDF digestibility estimates from in vivo data would be approximately $40 \%$ of this value because of changes in rumen retention time and passage rate. Taking this into consideration and assuming that a similar response would be expected with TMR digestibility, the change in NDF disappearance from the current study would then be $3.8 \%$. This should equate to an increase in milk production of $0.874 \mathrm{~kg}$ and an increase in DMI of $0.646 \mathrm{~kg}$. However, the milk response and DMI response was +0.4 and -0.2 $\mathrm{kg} / \mathrm{d}$ respectively. A portion of this difference could be explained by the shorter 21-d feeding period not providing enough time for adaptation. Additionally, as was discussed previously, the cows used in the current experiment may have been at a level of production or stage of lactation that allowed for BW gain (Table 3) rather than increased milk production. 
Table 3. Body weight, condition, and energy partitioning for cows on control (CON) or treatment (TRT) diets

\begin{tabular}{lcccc}
\hline Item & CON & TRT & SEM & $P$-value \\
\hline Initial BW (kg) & 690 & 687 & 19 & 0.51 \\
Final BW (kg) & 714 & 722 & 17 & 0.37 \\
BW change (kg/d) & 1.1 & 1.7 & 0.31 & 0.27 \\
Initial BCS & 3.30 & 3.30 & 0.05 & 0.99 \\
Final BCS & 3.28 & 3.32 & 0.05 & 0.29 \\
BCS change & -0.02 & 0.02 & 0.05 & 0.55 \\
Milk NE $_{\mathrm{L}}^{3}$ (Mcal/kg) & 0.72 & 0.73 & 0.01 & 0.56 \\
NE $_{\mathrm{L}}$ intake $^{4}$ (Mcal/d) & 40.1 & 41.8 & 1.72 & 0.33 \\
$\mathrm{NE}_{\mathrm{L}}$ intake (Mcal/kg of DMI) & 1.59 & 1.66 & 0.12 & 0.46 \\
Milk NE $_{\mathrm{L}}(\% \mathrm{NE}$ intake) & 65.9 & 64.1 & 1.39 & 0.34 \\
$\mathrm{NE}_{\mathrm{M}}\left(\% \mathrm{NE}_{\mathrm{L}}\right.$ intake) & 27.6 & 26.3 & 1.09 & 0.22 \\
\hline
\end{tabular}

${ }^{1} \mathrm{~A}$ significant period effect was observed for initial BW $(P<0.01)$ and final BW $(P<0.01)$.

${ }^{2}$ A significant block effect was observed for initial BW $(P=0.01)$ and final BW $(P<0.01)$.

${ }^{3} \mathrm{NE}_{\mathrm{L}(\text { milk })}(\mathrm{Mcal} / \mathrm{kg})=(0.0929 \times$ fat\% $)+(0.0547 \times$ protein\% $)+(0.0395 \times$ lactose $\%)(\mathrm{NRC}, 2001)$.

${ }^{4} \mathrm{NE}_{\mathrm{L}(\text { intake })}=\mathrm{NE}_{\mathrm{L}(\text { milk })}+\mathrm{NE}_{\mathrm{L}(\text { maintenance })}+\mathrm{NE}_{\mathrm{L}(\mathrm{BW} \text { gain })}$, where $\mathrm{NE}_{\mathrm{L}(\text { maintenance })}=0.08 \times \mathrm{BW}^{3 / 4}(\mathrm{NRC}, 2001)$.

\section{In Situ Experiment}

Effective degradability, disappearance rate, and fractions of $\mathrm{DM}, \mathrm{NDF}, \mathrm{ADF}$, and $\mathrm{CP}$ for $\mathrm{TMR}, \mathrm{AH}$, and
CS are shown in Tables 4, 5, and 6, respectively. Effective degradabilities of all nutrients were not affected by treatment. Likewise, the potentially degraded fraction (fraction B) or the undegraded fraction (fraction $\mathrm{C}$ )

Table 4. In situ disappearance characteristics for a control (CON) and treated (TRT) TMR incubated in cows fed a control $(\mathrm{CON})$ or treated (TRT) diet containing hemicellulose extract

\begin{tabular}{|c|c|c|c|c|}
\hline Item $^{1}$ & $\mathrm{CON}$ & TRT & SEM & $P$-value \\
\hline \multicolumn{5}{|l|}{$\mathrm{DM}(\%)$} \\
\hline A & 37.7 & 36.4 & 0.92 & 0.38 \\
\hline B & 46.4 & 41.6 & 2.86 & 0.24 \\
\hline $\mathrm{C}$ & 15.9 & 21.9 & 3.05 & 0.19 \\
\hline$K_{d}$ & 5.03 & 6.96 & 0.69 & 0.11 \\
\hline Effective degradability ${ }^{2}$ & 56.0 & 56.8 & 1.26 & 0.69 \\
\hline \multicolumn{5}{|l|}{$\operatorname{NDF}(\%)$} \\
\hline A & 9.6 & 20.2 & 1.16 & $<0.01^{*}$ \\
\hline B & 47.1 & 36.1 & 7.78 & 0.14 \\
\hline $\mathrm{C}$ & 43.3 & 43.7 & 8.01 & 0.94 \\
\hline $\mathrm{K}_{\mathrm{d}}$ & 6.29 & 5.21 & 1.01 & 0.40 \\
\hline Effective degradability $^{2}$ & 28.3 & 34.0 & 1.80 & 0.15 \\
\hline \multicolumn{5}{|l|}{$\operatorname{ADF}(\%)$} \\
\hline A & 11.3 & 17.1 & 0.83 & $0.03^{*}$ \\
\hline B & 47.0 & 33.6 & 10.4 & 0.14 \\
\hline $\mathrm{C}$ & 41.5 & 49.3 & 10.8 & 0.36 \\
\hline $\mathrm{K}_{\mathrm{d}}$ & 6.47 & 5.35 & 1.18 & $0.57 \dagger$ \\
\hline Effective degradability ${ }^{2}$ & 27.5 & 29.5 & 1.71 & 0.44 \\
\hline \multicolumn{5}{|l|}{$\mathrm{CP}(\%)$} \\
\hline $\mathrm{A}$ & 32.0 & 27.9 & 1.52 & 0.20 \\
\hline B & 66.2 & 59.3 & 3.74 & 0.32 \\
\hline $\mathrm{C}$ & 1.8 & 12.7 & 2.44 & 0.09 \\
\hline $\mathrm{K}_{\mathrm{d}}$ & 3.37 & 6.07 & 0.61 & 0.09 \\
\hline Effective degradability $^{2}$ & 53.5 & 54.5 & 1.86 & 0.73 \\
\hline \multicolumn{5}{|l|}{ Starch $(\%)$} \\
\hline A & 54.2 & 43.6 & 5.19 & 0.08 \\
\hline B & 45.2 & 56.4 & 5.03 & 0.06 \\
\hline $\mathrm{C}$ & 0.5 & 0 & 0.50 & 0.24 \\
\hline$K_{d}$ & 8.03 & 10.06 & 2.12 & 0.43 \\
\hline Effective degradability ${ }^{2}$ & 79.3 & 76.9 & 0.86 & $0.10^{*}$ \\
\hline
\end{tabular}

${ }^{1} \mathrm{~A}=$ immediately soluble fraction; $\mathrm{B}=$ potentially degraded fraction; $\mathrm{C}=$ undegraded fraction; $\mathrm{K}_{\mathrm{d}}=$ disappearance rate.

${ }^{2}$ Calculated as $\mathrm{A}+\mathrm{B}\left(\mathrm{K}_{\mathrm{d}} / \mathrm{K}_{\mathrm{d}}+\right.$ passage rate), where $\mathrm{K}_{d}=$ disappearance rate and the passage rates were calculated for each cow and feed based on individual BW and DMI.

*Significant period effects $(P<0.10)$; †significant period $\times$ treatment effects $(P<0.10)$. 
Table 5. In situ disappearance characteristics for alfalfa hay incubated in cows fed a control (CON) or treatment (TRT) diet containing hemicellulose extract

\begin{tabular}{|c|c|c|c|c|}
\hline Item $^{1}$ & $\mathrm{CON}$ & TRT & SEM & $P$-value \\
\hline \multicolumn{5}{|l|}{ DM $(\%)$} \\
\hline A & 32.4 & 26.7 & 0.89 & $0.04 * \dagger$ \\
\hline B & 35.2 & 41.6 & 1.15 & $0.06 \dagger$ \\
\hline $\mathrm{C}$ & 32.4 & 31.7 & 1.26 & $0.64^{*}$ \\
\hline $\mathrm{K}_{\mathrm{d}}$ & 8.03 & 11.04 & 0.83 & $0.05^{*}$ \\
\hline Effective degradability $^{2}$ & 55.6 & 56.7 & 1.30 & 0.57 \\
\hline \multicolumn{5}{|l|}{ NDF (\%) } \\
\hline A & 9.4 & 3.6 & 0.69 & $0.02 * \dagger$ \\
\hline B & 33.1 & 38.9 & 1.93 & 0.06 \\
\hline $\mathrm{C}$ & 57.5 & 57.5 & 2.22 & 0.99 \\
\hline $\mathrm{K}_{\mathrm{d}}$ & 6.30 & 10.28 & 0.83 & $<0.01^{*} \dagger$ \\
\hline Effective degradability $^{2}$ & 29.4 & 29.9 & 1.67 & 0.84 \\
\hline \multicolumn{5}{|l|}{$\operatorname{ADF}(\%)$} \\
\hline $\mathrm{A}$ & 8.0 & 3.1 & 0.54 & $0.02^{*} \dagger$ \\
\hline B & 35.5 & 39.4 & 2.03 & 0.13 \\
\hline $\mathrm{C}$ & 26.5 & 57.5 & 2.24 & 0.70 \\
\hline $\mathrm{K}_{\mathrm{d}}$ & 5.52 & 9.19 & 0.91 & $<0.01^{*}$ \\
\hline Effective degradability $^{2}$ & 28.2 & 28.5 & 1.76 & 0.90 \\
\hline \multicolumn{5}{|l|}{$\mathrm{CP}(\%)$} \\
\hline A & 35.7 & 27.9 & 2.23 & $0.13 \dagger$ \\
\hline B & 45.7 & 53.5 & 2.85 & 0.16 \\
\hline $\mathrm{C}$ & 18.7 & 18.6 & 1.72 & 0.98 \\
\hline $\mathrm{K}_{\mathrm{d}}$ & 7.99 & 11.92 & 1.61 & 0.18 \\
\hline Effective degradability $^{2}$ & 64.9 & 67.4 & 1.94 & 0.45 \\
\hline
\end{tabular}

${ }^{1} \mathrm{~A}=$ immediately soluble fraction; $\mathrm{B}=$ potentially degraded fraction; $\mathrm{C}=$ undegraded fraction; $\mathrm{K}_{\mathrm{d}}=$ disappearance rate.

${ }^{2}$ Calculated as $A+B\left(K_{d} / K_{d}+\right.$ passage rate), where $K_{d}=$ disappearance rate and the passage rates were calculated for each cow and feed based on individual BW and DMI.

*Significant period effects $(P<0.10)$; †significant period $\times$ treatment effects $(P<0.10)$.

was not affected, except for trends for greater DM and $\mathrm{NDF}$ disappearance of fraction $\mathrm{B}$ for $\mathrm{AH}$. The greatest response was observed with the disappearance of the immediately soluble fraction (fraction A) and the disappearance rate. Fraction A for AH and CS incubated in cows fed the TRT diet had less disappearance than those cows fed the CON diet, whereas fraction A for the TRT TMR had greater disappearance.

Interestingly, an increase in NDF (20.1 vs. 9.8\%) and $\mathrm{ADF}$ (17.5 vs. $12.1 \%$ ) disappearance was observed at the 0-h time point for TRT TMR compared with CON TMR. The 0-h time point in situ samples were never placed in the rumens of the cows. The TMR samples for each diet were collected before the start of the in situ portion of the experiment, dried, and weighed into Dacron bags. The fact that an increase in disappearance was observed at this time point would suggest an effect of HE separate from any rumen effect. It would seem likely that some fermentation occurred between collection of the TMR and processing before weighing into the bags that affected NDF and ADF disappearance.

The in situ results support the observations from the digestibility experiment that HE supplementation affects fiber digestibility. Although effective degrad- ability was not changed because of supplementation, the immediately soluble fraction was degraded to a larger extent and at a faster rate, especially for $\mathrm{AH}$ and TMR supplemented with HE. This would support the hypothesis that HE provides a source of sugars that optimizes rumen function. Corn silage would generally have a greater source of fermentable carbohydrates than $\mathrm{AH}$, and as a result, less of a response would be expected for the CS treatment.

\section{Rumen Measures}

Treatment did not affect most measurements of rumen parameters (Table 7). This is consistent with results from other researchers feeding sugars (Chamberlain et al., 1993). A significant reduction in acetate concentration occurred with the TRT diet. Chamberlain et al. (1993) also observed this type of response when individual sugars were being fed to sheep. Interestingly, the pattern of VFA change was quite different between TRT and CON. Although the average VFA concentrations and proportions throughout the 12-h period were not different, the VFA concentration for TRT increased much earlier than CON. Total VFA concentration $(\mathrm{m} M)$ was maximized between 3 and 6 
Table 6. In situ disappearance characteristics for corn silage incubated in cows fed a control (CON) or treatment (TRT) diet containing hemicellulose extract

\begin{tabular}{|c|c|c|c|c|}
\hline Item $^{1}$ & $\mathrm{CON}$ & TRT & SEM & $P$-value \\
\hline \multicolumn{5}{|l|}{$\mathrm{DM}(\%)$} \\
\hline A & 37.1 & 38.1 & 1.26 & 0.65 \\
\hline B & 35.2 & 34.9 & 1.26 & $0.90^{*}$ \\
\hline $\mathrm{C}$ & 27.6 & 26.9 & 1.49 & $0.74^{*}$ \\
\hline$K_{d}$ & 4.75 & 6.34 & 0.76 & $0.28^{*}$ \\
\hline Effective degradability $^{2}$ & 53.5 & 56.0 & 1.19 & 0.17 \\
\hline \multicolumn{5}{|l|}{ NDF (\%) } \\
\hline A & 7.1 & 6.1 & 1.94 & 0.78 \\
\hline B & 79.5 & 63.3 & 7.02 & $0.24^{*}$ \\
\hline $\mathrm{C}$ & 13.5 & 30.5 & 7.41 & $0.25^{*}$ \\
\hline $\mathrm{K}_{\mathrm{d}}$ & 1.70 & 4.27 & 0.43 & $0.05 * \dagger$ \\
\hline Effective degradability $^{2}$ & 25.1 & 28.3 & 1.97 & 0.24 \\
\hline \multicolumn{5}{|l|}{$\operatorname{ADF}(\%)$} \\
\hline A & 6.3 & 4.8 & 1.96 & 0.63 \\
\hline $\mathrm{B}$ & 78.7 & 61.9 & 8.03 & 0.28 \\
\hline $\mathrm{C}$ & 14.9 & 33.2 & 8.18 & 0.25 \\
\hline $\mathrm{K}_{\mathrm{d}}$ & 1.79 & 4.66 & 0.41 & $0.04^{* \dagger}$ \\
\hline Effective degradability ${ }^{2}$ & 24.8 & 27.8 & 2.01 & 0.22 \\
\hline \multicolumn{5}{|l|}{$\mathrm{CP}(\%)$} \\
\hline A & 60.4 & 53.2 & 2.74 & 0.20 \\
\hline B & 13.8 & 30.9 & 14.11 & 0.48 \\
\hline $\mathrm{C}$ & 25.8 & 15.8 & 13.03 & 0.61 \\
\hline$K_{d}$ & 22.29 & 6.38 & 11.62 & 0.40 \\
\hline Effective degradability ${ }^{2}$ & 55.4 & 59.7 & 3.05 & 0.34 \\
\hline \multicolumn{5}{|l|}{ Starch $(\%)$} \\
\hline A & 63.1 & 64.1 & 7.02 & 0.93 \\
\hline B & 36.8 & 35.9 & 7.02 & 0.94 \\
\hline $\mathrm{C}$ & 0.06 & 0.02 & 0.05 & 0.65 \\
\hline $\mathrm{K}_{\mathrm{d}}$ & 16.53 & 16.88 & 3.87 & 0.96 \\
\hline Effective degradability $^{2}$ & 91.1 & 91.6 & 0.54 & 0.58 \\
\hline
\end{tabular}

${ }^{1} \mathrm{~A}=$ immediately soluble fraction; $\mathrm{B}=$ potentially degraded fraction; $\mathrm{C}=$ undegraded fraction; $\mathrm{K}_{\mathrm{d}}=$ disappearance rate.

${ }^{2}$ Calculated as $\mathrm{A}+\mathrm{B}\left(\mathrm{K}_{\mathrm{d}} / \mathrm{K}_{\mathrm{d}}+\right.$ passage rate), where $\mathrm{K}_{\mathrm{d}}=$ disappearance rate and the passage rates were calculated for each cow and feed based on individual BW and DMI.

*Significant period effects $(P<0.10)$; †significant period $\times$ treatment effects $(P<0.10)$.

$\mathrm{h}$ for TRT, whereas CON did not reach maximum concentration until $9 \mathrm{~h}$ postfeeding. Furthermore, by $9 \mathrm{~h}$, it appeared as though VFA concentration for TRT had returned to the prefeeding concentration.

Acetate concentration numerically decreased with HE addition. Although the change was not significant, the difference along with a numerical increase in propionate concentration resulted in an acetate-topropionate ratio that was less for the TRT diet. This is in agreement with other in vivo experiments that reported a linear decrease in the ruminal acetate-topropionate ratio with increasing sugar concentration in the diet (Broderick et al., 2008). In mixed culture studies, fermentation of soluble starch in the presence of sugars and malate decreased the acetate-to-propionate ratio (Martin et al., 2000). Those authors also reported greater concentrations of acetate, propionate, and total VFA. However, that was an in vitro study and the current in vivo experiment may have provided an environment that promoted short-chain VFA utilization or absorption (Gäbel et al., 2002).

\section{CONCLUSIONS}

Hemicellulose extract supplementation positively affected fiber digestibility, particularly NDF digestibility. This response was observed both in situ as well as in total-tract apparent digestibility. Despite the increase in digestibility and potential energy, milk production was not increased. Supplementation of HE did not alter the majority of milk components. Additional research needs to be conducted to determine at what stage of lactation or level of production that dairy cows can benefit most from $\mathrm{HE}$ supplementation. It can be concluded that feeding $\mathrm{HE}$ is an effective feed additive to improve fiber digestibility in midlactation Holstein cows.

\section{ACKNOWLEDGMENTS}

The authors thank Temple-Inland Inc. (Austin, Texas) and the Higher Education Commission (Islamabad, Pakistan) for partial financial support of this research. 
Table 7. Least squares means of rumen fluid measures from cows fed a control diet (CON) or treatment diet (TRT) containing a hemicellulose extract

\begin{tabular}{|c|c|c|c|c|c|c|c|c|c|c|c|c|c|c|c|c|}
\hline \multirow[b]{3}{*}{ Item } & \multicolumn{5}{|c|}{$\mathrm{CON}$} & \multicolumn{5}{|c|}{ TRT } & \multirow{3}{*}{$\begin{array}{c}\mathrm{CON} \\
\text { average }\end{array}$} & \multirow{3}{*}{$\begin{array}{c}\text { TRT } \\
\text { average }\end{array}$} & \multirow{3}{*}{$\begin{array}{c}\text { SEM } \\
\text { of TRT } \\
\text { means }\end{array}$} & \multirow{2}{*}{\multicolumn{3}{|c|}{$P$-value $\mathrm{e}^{1,2}$}} \\
\hline & \multicolumn{5}{|c|}{ Hours after feeding } & \multicolumn{5}{|c|}{ Hours after feeding } & & & & & & \\
\hline & 0 & 3 & 6 & 9 & 12 & 0 & 3 & 6 & 9 & 12 & & & & Trt & Time & Period \\
\hline \multicolumn{17}{|l|}{ VFA $(\mathrm{m} M)$} \\
\hline Acetate & 56.2 & 55.5 & 65.9 & 74.6 & 66.1 & 58.8 & 67.3 & 66.1 & 57.9 & 53.3 & 63.6 & 59.9 & 1.71 & 0.01 & 0.39 & $<0.01$ \\
\hline Propionate & 20.2 & 21.4 & 25.5 & 28.6 & 26.9 & 20.7 & 25.8 & 28.2 & 24.2 & 25.4 & 24.5 & 24.9 & 1.88 & 0.42 & 0.07 & 0.90 \\
\hline Butyrate & 9.2 & 11.7 & 12.6 & 13.5 & 12.6 & 8.6 & 12.7 & 13.1 & 10.6 & 10.5 & 11.9 & 11.1 & 0.45 & 0.47 & 0.01 & 0.01 \\
\hline Isobutyrate & 1.06 & 0.85 & 0.86 & 0.83 & 0.82 & 1.06 & 0.96 & 0.82 & 0.69 & 0.69 & 0.88 & 0.84 & 0.03 & 0.73 & $<0.01$ & 0.01 \\
\hline Valerate & 1.21 & 1.31 & 1.40 & 1.45 & 1.34 & 1.17 & 1.53 & 1.61 & 1.37 & 1.35 & 1.34 & 1.41 & 0.05 & 0.72 & 0.30 & 0.08 \\
\hline Isovalerate & 1.65 & 1.42 & 1.43 & 1.40 & 1.35 & 1.68 & 1.64 & 1.51 & 1.29 & 1.24 & 1.45 & 1.47 & 0.07 & 0.34 & 0.01 & 0.03 \\
\hline Total & 89.5 & 92.1 & 107.7 & 120.4 & 109.1 & 92.1 & 109.9 & 111.3 & 92.1 & 92.6 & 103.8 & 99.6 & 2.25 & $<0.01$ & 0.03 & $<0.01$ \\
\hline \multicolumn{17}{|l|}{$\begin{array}{l}\text { VFA } \\
(\mathrm{mol} / 100 \mathrm{~mol})\end{array}$} \\
\hline Acetate (A) & 62.9 & 60.2 & 61.1 & 61.9 & 60.5 & 64.1 & 60.9 & 59.4 & 57.8 & 58.1 & 61.4 & 60.1 & 0.77 & 0.14 & $<0.01$ & 0.04 \\
\hline Propionate $(\mathrm{P})$ & 22.4 & 23.2 & 23.6 & 23.7 & 24.8 & 22.3 & 23.7 & 25.3 & 26.9 & 27.1 & 23.5 & 25.1 & 1.47 & 0.11 & $<0.01$ & 0.16 \\
\hline Butyrate & 10.3 & 12.7 & 11.9 & 11.2 & 11.5 & 9.3 & 11.6 & 11.7 & 11.5 & 11.2 & 11.5 & 11.1 & 0.26 & 0.08 & 0.08 & 0.31 \\
\hline Isobutyrate & 1.20 & 0.92 & 0.81 & 0.69 & 0.75 & 1.19 & 0.88 & 0.73 & 0.76 & 0.74 & 0.87 & 0.86 & 0.04 & 0.86 & $<0.01$ & 0.86 \\
\hline Valerate & 1.34 & 1.42 & 1.30 & 1.20 & 1.23 & 1.24 & 1.43 & 1.44 & 1.51 & 1.44 & 1.30 & 1.41 & 0.05 & 0.23 & 0.23 & 0.23 \\
\hline Isovalerate & 1.87 & 1.54 & 1.35 & 1.18 & 1.24 & 1.88 & 1.51 & 1.37 & 1.43 & 1.34 & 1.43 & 1.51 & 0.08 & 0.98 & $<0.01$ & 0.98 \\
\hline $\mathrm{A}: \mathrm{P}$ & 2.85 & 2.69 & 2.64 & 2.67 & 2.49 & 2.91 & 2.61 & 2.43 & 2.22 & 2.20 & 2.67 & 2.47 & 0.17 & 0.20 & $<0.01$ & 0.14 \\
\hline $\mathrm{NH}_{3}-\mathrm{N}(\mathrm{m} M)$ & 10.2 & 13.7 & 8.6 & 10.3 & 9.7 & 7.6 & 13.5 & 9.2 & 8.8 & 9.5 & 10.6 & 9.7 & 0.08 & 0.14 & 0.22 & 0.14 \\
\hline $\mathrm{pH}$ & 6.89 & 6.52 & 6.29 & 6.43 & 6.39 & 6.81 & 6.65 & 6.21 & 6.50 & 6.41 & 6.50 & 6.52 & 0.04 & 0.79 & $<0.01$ & 0.79 \\
\hline
\end{tabular}

${ }^{1}$ Significant $(P<0.01)$ treatment $($ Trt $) \times$ time interactions for mmol of acetate, total VFA, and mol/100 mol of valerate.

${ }^{2}$ Significant $(P<0.05)$ Trt $\times$ period interactions for mmol of butyrate, valerate, and $\mathrm{pH}$. 
We also like thank Anne C. Hopkins of Temple-Inland, Diboll, TX for her contributions.

\section{REFERENCES}

Abou Akkad, A. R., E. E. Bartley, and L. R. Fina. 1969. Ciliate protozoa in the rumen of the lactating cow. J. Dairy Sci. 52:1088-1091.

Akers, M. R. 2002. Functional development of the mammary gland Page 80 in Lactation and the Mammary Gland. I. S. Press, ed. Blackwell Publishing Company, Ames, Iowa.

AOAC. 2002. Official Method of Analysis. 18th ed. Association of Official Analytical Chemists, Gaithersburg, MD.

Bartley, E. E., E. L. Farmer, H. B. Pfost, and A. D. Dayton. 1968 Comparative value of dry and liquid hemicellulose extract and liquid cane molasses for lactating dairy cows. J. Dairy Sci. 51:706709 .

Broderick, G. A., N. D. Luchini, S. M. Reynal, G. A. Varga, and V. A. Ishler. 2008. Effect on production of replacing dietary starch with sucrose in lactating dairy cows. J. Dairy Sci. 91:4801-4810.

Broderick, G. A., and W. J. Radloff. 2004. Effect of molasses supplementation on the production of lactating dairy cows fed diets based on alfalfa and corn silage. J. Dairy Sci. 87:2997-3009.

Chamberlain, D. G., S. Robertson, and J.-J. Choung. 1993. Sugars versus starch as supplements to grass silage: Effects on ruminal fermentation and the supply of microbial protein to the small intestine, estimated from the urinary excretion of purine derivatives, in sheep. J. Sci. Food Agric. 63:189-194.

Chaney, A. L., and E. P. Marbach. 1962. Modified reagents for determination of urea and ammonia. Clin. Chem. 8:130-132.

Crawford, D. F., W. B. Anthony, and R. R. Harris. 1978. Evaluation of concentrated hemicellulose extract as cattle feed. J. Anim. Sci. 46:32-40.

Faber, T. A., L. L. Bauer, N. P. Price, A. C. Hopkins, and G. C. Fahey Jr.. 2011. In vitro digestion and fermentation characteristics of Temulose molasses, a coproduct of fiberboard production, and select Temulose fractions using canine fecal inoculum. J. Agric. Food Chem. 59:1847-1853.

Gäbel, G., J. R. Aschenbach, and F. Müller. 2002. Transfer of energy substrates across the rumen epithelium: Implications and limitations. Anim. Health Res. Rev. 3:15-30.

Glindemann, T., B. M. Tas, C. Wang, S. Alvers, and A. Susenbeth. 2009. Evaluation of titanium dioxide as an inert marker for estimating faecal excretion in grazing sheep. Anim. Feed Sci. Technol. 152:186-197.

Golombeski, G. L., K. F. Kalscheur, A. R. Hippen, and D. S. Schingoethe. 2006. Slow-release urea and highly fermentable sugars in diets fed to lactating dairy cows. J. Dairy Sci. 89:4395-4403.

Hall, M. B., C. C. Larson, and C. J. Wilcox. 2010. Carbohydrate source and protein degradability alter lactation, ruminal, and blood measures. J. Dairy Sci. 93:311-322.

Hartnell, G. F., and L. D. Satter. 1978. Effect of Masonex (hemicellulose extract) on protein degradation by rumen microorganisms in vitro and in vivo. J. Anim. Sci. 47:935-943.

Hoffman, P. C., and L. M. Bauman. 2003. Strategies to improve milk yield of lactating cows fed red clover silage. Prof. Anim. Sci. 19:178-187.
Kim, K. H., J.-J. Choung, and D. G. Chamberlain. 1999. Effects of varying the degree of synchrony of energy and nitrogen release in the rumen on the synthesis of microbial protein in lactating dairy cows consuming a diet of grass silage and a cereal-based concentrate. J. Sci. Food Agric. 79:1441-1447.

Magruder, N. D., C. B. Knodt, and P. S. Williams. 1953. Ammoniated industrial by-products in dairy heifer rations. Agric. Food Chem. 1:944-956.

Martin, S. A., H. M. Sullivan, and J. D. Evans. 2000. Effect of sugars and malate on ruminal microorganisms. J. Dairy Sci. 83:25742579 .

Myers, W. D., P. A. Ludden, V. Nayigihugu, and B. W. Hess. 2004 Technical Note: A procedure for the preparation and quantitative analysis of samples for titanium dioxide. J. Anim. Sci. 82:179-183.

NRC. 2001. Nutrient Requirements of Dairy Cattle. Natl. Acad. Sci. 7th rev. ed. NRC, Washington, DC.

Oba, M., and M. S. Allen. 1999. Evaluation of the importance of the digestibility of neutral detergent fiber from forage: Effects on dry matter intake and milk yield of dairy cows. J. Dairy Sci. $82: 589-596$.

Ørskov, E. R., and I. McDonald. 1979. The estimation of protein degradability in the rumen from incubation measurements weighted according to rate of passage. J. Agric. Sci. 92:499-503.

Orth, R. 1992. Sample day and lactation report. DHIA 200 Fact Sheet A-2. Mid-States Dairy Records Processing Center (DRPC), Ames, IA

Penner, G. B., and M. Oba. 2009. Increasing dietary sugar concentration may improve dry matter intake, ruminal fermentation, and productivity of dairy cows in the postpartum phase of the transition period. J. Dairy Sci. 92:3341-3353.

Robertson, J. B., and P. J. Van Soest. 1981. The detergent system of analysis and its application to human foods. Pages 123-158 in The Analysis of Dietary Fiber in Food. W. P. T. James and O. Theander, ed. Marcel Dekker Inc., New York, NY.

SAS Institute. 2008. SAS User's Guide: Statistics. Version 9.08. SAS Institute Inc., Cary, NC.

Shreve, B., N. Thies, and M. Wolf. 2006. NFTA method 2.1.4. Dry Matter by oven drying for 3 hours at $105^{\circ} \mathrm{C}$. National Forage Testing Association, Omaha, NE. Accessed Oct. 31, 2011. http://www. foragetesting.org/files/NFTAReferenceMethodDM-09-18-06.pdf.

Tunc, M. S., and A. R. P. van Heiningen. 2008. Hemicellulose extraction of mixed southern hardwood with water at $150^{\circ} \mathrm{C}$ : Effect of time. Ind. Eng. Chem. Res. 47:7031-7037.

Van Soest, P. J., J. B. Robertson, and B. A. Lewis. 1991. Methods for dietary fiber, neutral detergent fiber, and non-starch polysaccharides in relation to animal nutrition. J. Dairy Sci. 74:3583-3597.

Walton, S. L. 2005. Biological conversion of hemicellulose extract into value-added fuels and chemicals. $\mathrm{PhD}$ Thesis. University of Maine, Orono.

Wiedmeier, R. D., B. H. Tanner, J. R. Bair, H. T. Shenton, M. J. Arambel, and J. L. Walters. 1992. Effects of a new molasses byproduct, concentrated separator byproduct, on nutrient digestibility and ruminal fermentation in cattle. J. Anim. Sci. 70:1936-1940.

Wildman, E. E., G. M. Jones, P. E. Wagner, R. L. Bowman, H. F. Troutt Jr., and T. N. Lesch. 1982. A dairy cow body condition scoring system and its relationship to standard production characteristics. J. Dairy Sci. 65:495-501. 